\title{
Detection of Bacteriological Contaminants in Hand-Pump Fitted Borehole Water from a Residential Suburb in Ringim Local Government, Jigawa State
}

\author{
${ }^{*}$ A.O. Adeleye, ${ }^{1}$ B.Kabiru, ${ }^{1}$ A.O.Amoo, ${ }^{2}$ F.K. Amoo, ${ }^{2}$ M.Raji, ${ }^{1}$ G.B. Bate, ${ }^{1 B}$ B.Yalwaji and \\ 2M.B.Yerima \\ 1Department of Environmental Sciences, Federal University Dutse, Dutse, Jigawa State \\ 2Department of Microbiology and Biotechnology, Federal University Dutse, Dutse, Jigawa State
} [ ${ }^{\star}$ Corresponding Author: E-mail: adeniyi.adeleye@fud.edu.ng; $\left.\mathbf{P}:+234(0) 8162784457\right]$

\section{ABSTRACT}

Water from borehole source can be contaminated due to indiscriminate waste disposal. This pilot study was conducted to assess the bacteriological quality of water from five (5) hand-pump-fitted borehole sources present in Sabon Gari quarters in Ringim Local Government Area of Jigawa State. Presumptive, confirmed and completed tests were employed to determine total and faecal coliforms from the water samples using most probable number (MPN) technique. Bacterial isolates were identified by standard microbiological methods. Results obtained indicate that all the water samples across all the dilution strengths tested recorded substantial growth of total coliforms at $37.3^{\circ} \mathrm{C}$ while faecal coliforms were observed at $44^{\circ} \mathrm{C}$ after incubation for $48 \mathrm{~h}$. Using the MPN table, the five water samples assayed recorded $50 \mathrm{MPN} / 100 \mathrm{~mL}, 14$ MPN/100mL, $3 \mathrm{MPN} / 100 \mathrm{~mL}, 5 \mathrm{MPN} / 100 \mathrm{~mL}$ and $1 \mathrm{MPN} / 100 \mathrm{~mL}$. Results were also positive for gas and acid production in all samples collected characteristic of presence of $E$. coli. The results obtained in this study show bacterial contamination of the water from the boreholes which may constitute a public health risk. It is therefore recommended that the water pumped from these boreholes should be subjected to adequate treatment to meet World Health Organization (WHO) required standard for potable water meant for drinking.

Keywords: Boreholes, hand pump, most probable number, total coliforms and faecal coliforms.

\section{INTRODUCTION}

The utilization of water for numerous daily activities remains undoubtedly the highest need that humans have not got alternatives to as it is inevitable. According to Tya et al. (2012), water is certainly one of the most indispensable resources on earth and remains the most needed resource that man needs in his immediate environment. Accessibility and nearness of potable water for human consumption has been pinpointed by Adeleye et al. (2018) as vital features that divulge suitable welfare of humans in their environment. The scarcity of water in some remote areas of Nigeria has necessitated the utmost need of constructing hand-pump boreholes which is normally bored into the underground aquifer for domestic, agricultural and industrial use (Palamulen and Akoth, 2015). Many authors (Singh and Mosley, 2003; Bello et al., 2013; Palamulen and Akoth, 2015; Hassan et al., 2018; Amoo et al., 2018) have submitted that groundwater resources which are supposed to be free from pollution becomes vulnerable to contamination due to indiscriminate disposal of waste materials, poor siting of drainages, proximity of septic tanks to groundwater source and extensive use of environmental contaminating chemicals in the agricultural and industrial sectors.

The importance of bacteriological assessment of water portability has been variously reported (Adetunde and Glover, 2010; Amoo et al., 2018; Bekuretsion et al., 2018; Hassan et al., 2018; Onuorah et al., 2018; Onuorah et al., 2019). For example, the presence of faecal coliforms or Escherichia coli in water clearly indicates that such waters have got the presence of water borne pathogens (Okpokwasili and Akujobi, 1996). According to Singh and Neelam (2011), bacteriological analysis of water is a potent tool that is adopted in detecting the presence of 
microorganisms that might institute health hazards. However, World Health Organization (WHO) has recommended that faecal coliform expected to be found in drinking water should be zero cfu/100mL (Tya et al., 2012).

Ringim is a developing town in Jigawa state, and a major source of household water supply is through community borehole projects by local authorities. Evidently, septic tanks and gutters for disposal of waste are in close proximity to the hand-pump boreholes present in the study area which may leak into the aquifer thereby polluting the groundwater. It is against this backdrop that this study was conducted with a view to ascertaining the portability of the hand-pump borehole water for domestic use by the residents of Sabon Gari quarters in Ringim.

\section{MATERIALS AND METHOD \\ The Study Area}

Ringim is the headquarter of Ringim Local Government Area (LGA) of Jigawa State, Nigeria that has an area of $1,057 \mathrm{~km}^{2}$ with a population around 192,024 recorded during 2006 census
(Jigawa State Government, 2017) with farming as the primary occupation during the wet and dry seasons. As shown in Figure 1, Ringim is located at $12.15^{\circ}$ North latitude, $9.16^{\circ}$ East longitude and about 387 meters elevation above the sea level (Maps, 2019).

\section{Water Sample Collection}

Water was aseptically sampled from the five (5) sampling points (boreholes) in the study area designated as BHA, BHB, BHC, BHD and BHE (Table 1). Sample collection was done at the beginning of wet season in May, 2019. Adopting the method described by Amoo et al. (2018), water samples were collected in clean sterile one (1) litre plastic containers rinsed with de-ionized water before being used (USFDA, 2018) at the point of collection. Each sample bottle was well labeled according to respective sampling location. All the samples were subsequently preserved at $4^{\circ} \mathrm{C}$ and immediately transported to the laboratory for onward bacteriological analysis.

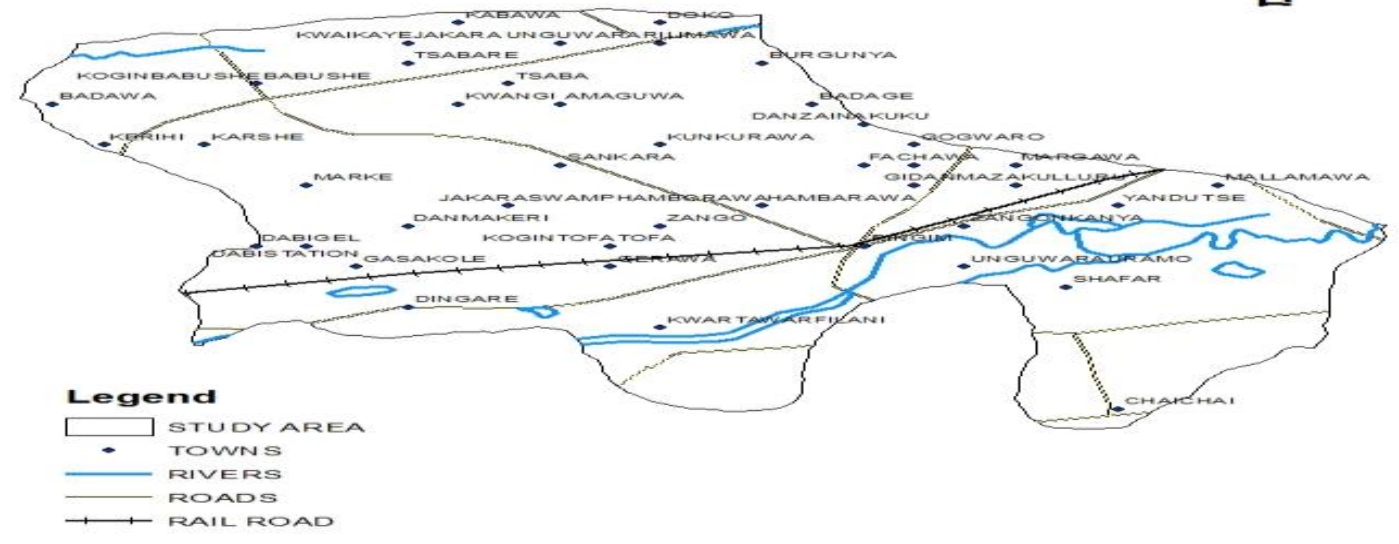

995390000680,090170,00660,000 $1 \mathrm{~cm}=3 \mathrm{~km}$

Figure 1: Map showing the study area 
Table 1: Location of the assayed boreholes in the study area

\begin{tabular}{ll}
\hline $\begin{array}{l}\text { Street Name } \\
\text { Location }\end{array}$ & $\begin{array}{l}\text { Acronym for Sampling } \\
\text { point }\end{array}$ \\
\hline HarunaKassim1 & BHA \\
Muttaka Dodo 1 & BHB \\
Muttaka Dodo 2 & BHC \\
Sale Maidodo & BHD \\
HarunaKassim2 & BHE \\
\hline
\end{tabular}

\section{Physicochemical Analyses of the Water Samples}

All the sampled water from each sampling point was subjected to various physicochemical analyses; temperature, $\mathrm{pH}$, turbidity, electrical conductivity $(\mathrm{EC})$, total hardness and nitrite were measured using thomas high-accuracy thermometer, pocket pro pH tester, 2100Q portable turbidimeter, HQ430D laboratory single input multi-parameter meter, SP510 hardness analyzer and EZ7750nitrite analyzer respectively. These parameters were analyzed following the standard analytical methods outlined by APHA (2012).

\section{Determination of Total and Faecal Coliforms in the Water Samples}

Tests for determining total and faecal coliforms in the water samples collected were conducted in three stages: presumptive, confirmed and completed tests briefly described below:

\section{Presumptive test}

Total coliform was derived by adopting the procedure prescribed by Ochei and Kolhatkar (2008).This was done by employing a three (3) tube assay of the Most Probable Number (MPN) technique and sterilized MacConkey broth. Fifty (50) $\mathrm{mL}$ of water was aseptically dispensed into a sterilized test tube containing $50 \mathrm{~mL}$ of double strength MacConkey broth, $10 \mathrm{~mL}$ of water was dispensed into five (5) sterilized test tubes containing $10 \mathrm{~mL}$ single strength MacConkey broth and $1 \mathrm{~mL}$ of water was dispensed into five (5) test tubes containing $5 \mathrm{~mL}$ single strength MacConkey broth. All the test tubes employed contained sterilized Durham tubes for gas entrapment. The test tubes were subsequently incubated at $37.3^{\circ} \mathrm{C}$ and $44^{\circ} \mathrm{C}$ for $48 \mathrm{~h}$ to estimate total and faecal coliforms respectively. After incubation, the test tubes were examined for acid and gas production. A change in the colour of the broth from reddish purple to yellow was recorded as acid production while the presence of bubbles and gas entrapment in the Durham tubes indicated gas production. The MPN was subsequently determined using appropriate MPN table.

\section{Confirmed test}

Confirmed test was conducted in accordance with the procedure established by Majula et al. (2011). This was done by aseptically transferring a loopful of culture from positive test tubes in the presumptive test into plates containing sterilized Violent Red Blue Agar (VRBA) and test tubes containing sterilized peptone water. The plates and test tubes were subsequently incubated as described previously for total and faecal coliforms respectively. The production of gas and emergence of red colour indicating indole production in peptone water employed were recorded as a positive result for the presence of $E$. coli while growth of pink colonies with metallic sheen and bleaching at center on VRBA confirmed the presence of coliforms.

\section{Completed test}

Completed test was carried out as prescribed by WHO (2012). This was done by streaking positive results from the confirmed test on sterilized Eosin Methylene Blue (EMB) agar with a view to obtaining discrete colonies. The plates were subsequently incubated at $37.3^{\circ} \mathrm{C}$ for $48 \mathrm{~h}$. Development of green metallic sheen colonies on EMB was recorded as a completed test for further identification of coliforms or faecal coliforms (Escherichia coli) as established by Adetunde and Glover (2010). 


\section{Gram Staining}

In other to conduct morphological identification of the bacterial isolates, gram staining was done according to the procedure recommended by Olutiola et al. (1991).

\section{Biochemical tests for the identification of coliforms}

After gram staining, all the assayed water samples from the sampling points came up as gram negative rods thereby prompting the need to further confirm their possible identities through the conduct of appropriate biochemical tests recommended by Barrow and Feltham (1993). Biochemical characterization was carried out to identify bacterial isolates by conducting the following tests: catalase, indole, methyl red and vogesproskauer (Cheesebrough, 2006); citrate, oxidase, urease, nitrate reduction and gelatin (Ochei and Kolhatkar, 2008); mannitol, lactose and triple sugar iron (Hemraj et al. 2013); oxidation fermentation and glucose (Aryal, 2018)

\section{Statistical Analysis}

Most Probable Number (MPN) analysis which is based on the random spreading of microorganisms per volume in any given sample as described by Aryal (2018) was adopted in analyzing data generated from the presumptive, confirmed and completed tests. Data generated from physicochemical and bacteriological analyses were subsequently summarized in tables and compared with WHO permissible standards.

\section{RESULTS AND DISCUSSION}

Results of the physicochemical analyses of the sampled boreholes as presented in Table 2 show that temperature of borehole water samples measured during water sample collection, for $\mathrm{BHA}, \mathrm{BHB}, \mathrm{BHC}, \mathrm{BHD}$ and $\mathrm{BHE}$ are $34^{\circ} \mathrm{C}, 33^{\circ} \mathrm{C}$, $31^{\circ} \mathrm{C}, 33^{\circ} \mathrm{C}$ and $32^{\circ} \mathrm{C}$ respectively. Even though WHO has not recommended any temperature standard for potable water, Palamuleni and Akoth (2015) reported that it does enhance the total quality of water in terms of its biological and physicochemical attributes. The total hardness of the water samples that ranged from 105.8 to 48.6 $\mathrm{mg} / \mathrm{L}$ fell below the permissible limit recommended by WHO. It can be observed that $\mathrm{pH}$ values ranged from 7.8 to 7.2 . Interestingly, the $\mathrm{pH}$ values recorded in this study fell within the recommended limits set by WHO. Similar findings were reported by Amoo et al. (2018) who conducted water quality assessment of selected boreholes in a geological location similar to the area of this study.

Table 3 presents results for determining the presence of coliforms in the water samples. All the samples demonstrated substantial growth of total and faecal coliforms suggesting microbiological contamination of the borehole water under study.

Table 2: Physicochemical parameters recorded from the sampling points

\begin{tabular}{lcccccc}
\hline & BHA & BHB & BHC & BHD & BHE & WHO \\
\hline pH & 7.8 & 7.4 & 7.2 & 7.7 & 7.3 & $\geq 7$ to $\leq 9.2$ \\
$\mathrm{~T}(0 \mathrm{C})$ & 34 & 33 & 31 & 33 & 32 & No standard \\
$\mathrm{TH}(\mathrm{mg} / \mathrm{L})$ & 105.8 & 87.3 & 65.4 & 68.7 & 48.6 & 150 to 500 \\
$\mathrm{EC}(\mu \mathrm{S} / \mathrm{cm})$ & 585 & 570 & 462 & 465 & 420 & 1000 \\
$\mathrm{Tu}(\mathrm{NTU})$ & 3.04 & 2.15 & 0.16 & 1.05 & 0.05 & 5 \\
Nitrite $(\mathrm{mg} / \mathrm{L})$ & 0.06 & 0.03 & 0.01 & 0.01 & 0.01 & 50 \\
\hline
\end{tabular}

Note: $\mathrm{T}=$ Temperature; $\mathrm{TH}=$ Total Hardness; $\mathrm{EC}=$ Electrical Conductivity; $\mathrm{Tu}=$ Turbidity 
Nigerian Journal of Basic and Applied Science (December, 2020), 28(2): 81-88

Table 3: Water assay results for all the sampling points in SabonGari Quarters

\begin{tabular}{c|ccc|ccc|ccc}
\hline Sample & \multicolumn{3}{|c|}{ Growth } & \multicolumn{3}{c|}{ Acid Production } & \multicolumn{3}{c}{ Gas Production } \\
& $50 \mathrm{~mL}$ & $10 \mathrm{~mL}$ & $1 \mathrm{~mL}$ & $50 \mathrm{~mL}$ & $10 \mathrm{~mL}$ & $1 \mathrm{~mL}$ & $50 \mathrm{~mL}$ & $10 \mathrm{~mL}$ & $1 \mathrm{~mL}$ \\
\hline BHA & Yes & Yes & Yes & + & + & + & + & + & + \\
BHB & Yes & Yes & Yes & + & + & + & + & + & + \\
BHC & Yes & Yes & Yes & + & + & + & + & + & + \\
BHD & Yes & Yes & Yes & + & + & + & + & + & + \\
BHE & Yes & Yes & Yes & + & + & + & + & + & + \\
\hline
\end{tabular}

Note: + = Positive

In terms of acid production by the total and faecal coliforms that grew in the water samples, all recorded positive results across the dilution strengths employed (Table 3). These results indicate the presence of total and faecal coliforms in all the water samples as indicator organisms have been implicated by Ochei and Kolhatkar (2008) as having the ability of producing acid when incubated at the aforeindicated temperature ranges employed in this study. Again, the detection of gas in all the Durham tubes employed in this study indicates the presence of total and faecal coliforms in all the water samples assayed (Table 2).

The quantification of the coliform bacteria present in the water samples assessed in this study through the employment of most probable number (MPN) table is depicted in Table 4.

It can be seen that the MPN values ranged from $1-50 \mathrm{~mL}$ across the five sampling points (Table 4). Samples from BHE (1 mL) and BHA (50mL) recorded the lowest and highest MPN/100mL respectively. The variations observed in the total and faecal coliforms present in the study area may be due to different sources and proximity of pollutants responsible in each sampling point. For instance, physical inspection of BHA during sampling revealed its proximity to drainages and septic tanks that might have potentially contributed to the pollution level recorded in this study. Again, the incessant flooding experienced in the study area prior to water sampling might be held responsible for the presence of coliform bacteria in the groundwater of that locality. The results obtained in this study are in concord with the reports of Adetunde and Glover (2010); Kamanula et al. (2014). These authors implicated the location of the boreholes assayed in their respective studies and some environmental factors as determinants of pollution level that groundwater is exposed to these days.

The results of the biochemical tests conducted (Table 5) confirmed the presence of $E$. coli. The gram negative rod tested positive to catalase, $\mathrm{OF}$, indole and MR tests but negative to VP, citrate and TSI.

Table 4: MPN Values for the water samples collected from the sampling points

\begin{tabular}{lll}
\hline Sample & Ratio & $\begin{array}{l}\text { MPN Values } \\
\text { (MPN/100mL) }\end{array}$ \\
\hline BHA & $1: 5: 2$ & $50 \mathrm{~mL}$ \\
BHB & $1: 3: 2$ & $14 \mathrm{~mL}$ \\
BHC & $1: 1: 0$ & $3 \mathrm{~mL}$ \\
BHD & $1: 1: 1$ & $5 \mathrm{~mL}$ \\
BHE & $0: 1: 0$ & $1 \mathrm{~mL}$
\end{tabular}

Key: MPN= Most Portable Number 
Table 5: Biochemical Screening of Gram Negative Rods Detected in Borehole water Samples

\begin{tabular}{cccccccccccccccc}
\hline & CA & OF & MR & VP & GL & LA & MA & GE & NR & UR & CI & OX & IN & TSI & Identity \\
\hline $\mathrm{BHA}$ & + & + & + & - & + & + & + & - & + & - & - & - & + & - & E. coli \\
$\mathrm{BHB}$ & + & + & + & - & + & + & + & - & + & - & - & - & + & - & E. coli \\
$\mathrm{BHC}+$ & + & + & + & - & + & + & + & - & + & - & - & - & + & - & E. coli \\
$\mathrm{BHD}$ & + & + & + & - & + & + & + & - & + & - & - & - & + & - & E. coli \\
$\mathrm{BHE}$ & + & + & + & - & + & + & + & - & + & - & - & - & + & - & E. coli \\
\hline
\end{tabular}

Key: + = Positive; - = Negative; CA= Catalase; OF= Oxidation Fermentation; MR= Methyl Red; VP= Voges-Proskauer; TSI = Triple Sugar Iron; $\mathrm{GL}=$ Glucose; LA= Lactose; $\mathrm{MA}=$ Mannitol; $\mathrm{GE}=$ Gelatin; NR= Nitrate reduction; UR= Urease; $\mathrm{Cl}=\mathrm{Citrate}$; $\mathrm{OX}=$ Oxidase; $\mathrm{IN}=$ Indole

\section{CONCLUSION AND RECOMMENDATIONS}

The findings of this study have detected the presence of Escherichia coli in all the sampled borehole water hence not fit for human consumption. It is recommended that the water from these boreholes should be treated with disinfectants before use for domestic purposes most especially drinking. Routine monitoring and assessment of the borehole water quality in the study area is important to avert public health crisis.

\section{CONFLICT OF INTEREST}

The authors declare that there is no conflict of interest.

\section{REFERENCES}

Adeleye, A. O., Orifah, M. O., Amoo, A. O., ljanu, E. M., Shuaibu, S. J. and Hassan, A. (2018). Artisans' Knowledge and Perception on Hand-Dug Well Waterborne Related Diseases in Dutse Mechanic Village North-West, Nigeria.Journal of Applied Sciences and Environmental Management, 22(10): 1603-1607.

Adetunde, L. A. and Glover, R. L. K. (2010).Bacteriological Quality of Borehole Water Used by Students' of University for Development Studies, Navrongo Campus in Upper-East Region of Ghana.Current Research Journal of Biological Sciences, 2(6): 361-364.

American Public Health Association (APHA) (2012). Standard Methods for the Examination of Water and Wastewater, 22nd edition edited by E. W. Rice, R. B. Baird, A. D. Eaton and L. S. Clesceri. American Water Works Association (AWWA) and Water Pollution Control Federation (WPCF).Washington,D.C.

Amoo, A. O., Adeleye, A. O., Bate, G. B., Okunlola, I. A. and Hambali, I. B. (2018). Water Quality Assessment of Selected Boreholes in Federal University Dutse Campus North-West, Nigeria.Umaru Musa Yaradua University Journal of Microbiology Research, 3(2):20-26.

Aryal, S. (2018).Water Quality Analysis by Most Probable Number (MPN).https://microbenotes.com/waterquality-analysis-by-most-probablenumber-mpn/. Accessed on August 2nd, 2019.

Barrow, G.I. and Feltham, R.K.A. (1993). Cowan and Steel's Manual for the Identification of Medical Bacteria. Cambridge University Press 3rd Edition.Pp 52-101. Retrieved from https://www.academia.edu/8106702/Cow an_and_Steels_manual_for_the_identific ation_of_medical_bacteria_COWAN_AN D_STEELS_Manual_for_the_identificatio n_of_medical_bacteria_THIRD_EDITION _EDITED_AND_REVISED_BY.Accesse d on May 2nd, 2019.

Bekuretsion, H., Hailekiros, H., Niguse, S., Asmelash, T.,Abdulkader, M., Saravanan, M. and Brindhadevi, K. (2018). Bacteriological Assessment of Drinking Water from Hand-Pump-Fitted Borehole Sources in Kola Tembien, 


\section{Nigerian Journal of Basic and Applied Science (December, 2020), 28(2): 81-88}

Central Tigray.Northern Ethiopia. Journal of Water Supply: Research and Technology-Aqua, 67(8): 790-799.

Bello O. O., Osho A., Bankole S. A., Bello T. K. (2013). Bacteriological and Physicochemical Analyses of Borehole and Well Water Sources in ljebu-Ode, Southwestern Nigeria. International Journal of Pharmacy and Biological Sciences, 8: 18-25.

Cheesebrough, M. (2006). District Laboratory Practice in Tropical Countries, part II. 2nd Ed. New York: Cambridge University Press. Chapter 7.Pp.38-158.

Hassan, A., Kura, N. U., Amoo, A. O., Adeleye, A. O., ljanu, E. M., Bate, G. B. Amoo, N. B. and Okunlola, I. A. (2018). Assessment of Landfill Induced Ground Water Pollution of Selected Boreholes and Hand-Dug Wells around UltraModern Market Dutse North-West, Nigeria. The Environmental Studies, 1(4): 1-10.

Hemraj, V., Diksha, S. and Avneet, G. (2013).A Review on Commonly Used Biochemical Test for Bacteria.Innovare Journal of Life Science, 1(1): 1-7.

Jigawa State Government (2017).Ringim Emirate.Available at http://www.jigawastate.gov.ng/ringim.php .Accessed on July 28, 2019.

Kamanula, J. F., Zambasa, O. J. and Masamba, W. R. L. (2014).Quality of Drinking Water and Cholera Prevalence in Ndirande Township, City of Blantyre, Malawi. Physics and Chemistry of the Earth, 72-75: 61-67.

Majula, A. V., Shankar, G. K and Preeti, S. M. (2011).Bacteriological Analysis of Drinking Water Samples.Journal of Microbiology, 18(1-2): 387-391.

Maps (2019). Map of Ringim, Jigawa State - road map, satellite view and street view. Available at https://www.mapsstreetview.com/Nigeria/Ringim/.Accesse d on July 26th, 2019.
Mustafa, A. I., Ibrahim, A. A., Haruna, Y. I. and Abubakar, S. (2013). Physicochemical and Bacteriological Analysis of Drinking Water from Wash Boreholes in Maiduguri Metropolis, Borno State Nigeria. African Journal of Food Science, 7(1): 9-13.

Ngele, S. O., Itumoh, E. J., Onwa, N. C. and Alobu, F. (2014). Quality Assessment of selected Ground Water Samples in Amike-Aba, Abakaliki, Ebonyi State, Nigeria.Canadian Journal of Pure and Applied Science, 8(1): 2801-2805.

Ochei, J. $\mathrm{O}$ and Kolhatkar, A. A. (2008). Medical Laboratory Science: Theory and Practice. Tata McGraw Publishing Company Limited. Seventh Edition. Pp 637-745.ISBN 10:007463223X/ISBN 13: 9780074632239

Okpokwasili, G. C. and Akujobi, T. C. (1996). Bacteriological Indicators for Tropical Water Quality. Environmental Toxicology Water Quality, 11: 77-81.

Onuorah, S., Igwemadu, N. and Odibo, F. (2019).Bacteriological Quality Assessment of Borehole Water in Ogbaru Communities, Anambra State, Nigeria.Universal Journal of Clinical Medicine, 7(1): 1-10.

Onuorah, S., Nwoke, J. and Odibo, F. (2018).Bacteriological Assessment of the Public Hand-Pump Borehole Water in Onueke, Ezza South Local Government Area, Ebonyi State, Nigeria. International Journal of Photochemistry and Photobiology, 2(2): 39-48.

Olutiola, P.O., Famurewa, O., Sontag, H.G. (1991). An Introduction to General Microbiology.A Practical Approach.1st Edition.Heidelberger Verlagsanstalt and Druckerei GmbH Heldelberg, Germany. Pp 257 ISBN: 3- 89426-0.

Palamulen, L. and Akoth, M. (2015).PhysicoChemical and Microbial Analysis of Selected Borehole Water in Mahikeng, South Africa.International Journal of Environmental Research and Public Health, 12(8): 8619-8630. 
Singh, S. and Mosley, L. M. (2003). Trace Metal Levels in Drinking Water on Viti Levu, Fiji Islands. South Pacific Journal of Natural Science, 21: 31-34.

Singh, V. P. and Neelam, S. (2011). A Survey Report on Impact of Abattoir Activities and Management on Residential Neighbourhoods. Indian Journal of Veterinarians, 6(3): 973-978.

Tya, T. S. K., Umaru, A. B. and Barmamu, B. R. (2012).Bacteriological Analysis of HandDug Well Water in Demsa Local Government Area, Nigeria.International Refereed Journal of Engineering and Science, 1(4): 28-31.
United State Food and Drug Administration (USFDA) (2018). Bacteriological Analytical Manual (BAM) Chapter One: Food Sampling and Preparation of Sample Homogenate. Available at https://www.fda.gov/food/foodscienceres earch/laboratorymethods/ucm063335.ht m. Retrieved on 26th July 2019.

World Health Organisation (WHO) (2012). Guidelines for Standard Operating Procedures for Microbiology: In Bacteriological Examination of Water. World Health Organization Regional Office for South-East Asia. 